time of the dinosaurs, and they and all their immediate kin have disappeared for ever, and new and unforescen trends of life have blossomed, as they have done over and over again, and have carried the story of evolution on to the present, when man is the dominant and highest.

Looking back over that 1,200-million-year vista of the steady climb of life upon the path of evolution, it seems presumptuous for us to suppose that man, the latest newcomer, is the last word or the final crowning glory amongst many, and that with his coming the great steps in evolution have come to an end. Looking forward to the future of life upon the earth, it seems even more presumptuous for us to suppose that for the next 1,000 million years life, so surprisingly inventive in the past, should be tied for all time to come to trifling changes like increase of brain power or better social organization for mankind.

The truth is that we, bound by the past, can imagine nothing more, but if the long vista of evolution is any clue to the future, we cannot regard mankind, the crowning glory of the present, to be more than a stage in life's progress and a milestone upon the path of evolution towards a greater future. To think otherwise is to imagine that with the coming of man, so insignificant in time, the advance and inventiveness of evolution, steadily carried on through an unimaginable vista of years in which no trace of slackening can be perceived, has all but come to an end.

It may seem to you that our perspectives have carried us far afield into a future so remote that it is scarcely worthy of consideration. My excuse must be that we are so accustomed to think of man as the sole significant inhabitant of the world that it is worth while now and again to look upon him in his biological setting as but one, and yet so far the greatest, of the manifestations of life upon the earth.

\title{
THE FUTURE OF FLYING*
}

\author{
By Dr. H. E. Wimperis, C.B., C.B.E.
}

\section{Lately Director of Scientific Research, Air Ministry}

$\mathrm{E}^{\mathrm{v}}$ VER since man inhabited the earth, he has lived not by his physical powers, which are slight, but by the exercise of his wits. Every new invention he has made has had its warlike use as well as its peaceful purpose, and each has challenged his wits to ensure that good rather than harm shall result from the new discovery. To bend the newest invention of all, the conquest of the air, to the service of mankind is now his great task. In it, success is essential lest we presently find that it is the air that has conquered mankind rather than mankind the air. Before we can regard the conquest of the air as achieved, we must control the warlike menace.

$I$ believe that the scientific advances of the present time, and their probable development in the near future, will help us to solve, and not to aggravate, our central problem-the task Lawrence of Arabia spoke of as "the biggest thing to do in the world to-day"- to bend the newest invention of all, the conquest of the air, to the true service of mankind.

Mechanical flight was achieved when Wilbur Wright flew in December 1903 in that odd-looking machine now so proudly housed in the Science Museum at South Kensington. It certainly does

- From the presidential address to Section $G$ (Engineering) of the British Association, delivered at Dundee on August 31 . look a queer machine to modern eyes. Although the engine weighed $180 \mathrm{lb}$., it gave but 12 h.p.! Of course it was natural that this, like all the other early aeroplanes, should be built with two pairs of wings. Engineers were well accustomed to carrying bending moments by a form of girder construction having an upper and a lower boom, and in the biplane form of construction the loads could be carried in this familiar way. Such early trials as were made of the monoplane type merely seemed to confirm the idea that a strong wing structure could not thus be found, and the biplane became the accepted type. Speeds in those days were low, and even long after the war of 1914-18 it was thought that the attainment of high speed would be mainly a matter of putting in more and more engine power. More and more power was accordingly put in. This led indeed to the achievement of higher speeds, but far-sighted designers saw that there was a limit to the extent of progress by this means. But, as a Spanish proverb has it : "When one door shuts another opens". The new door in this case proved to be the streamlining of the external form of the craft as a whole.

That the cleaning up of the aerodynamic structure could carry performance much further than had hitherto been realized, and do so without any increase of engine power, was first clearly 
pointed out, little more than ten years ago, by Prof. B. MI. Jones of Cambridge.

\section{FLYING TO-DAY}

The consequence of these and other changes in design from the original Wright machine brought a steady growth in speed, which during the last score of years has increased by an average of well over 10 miles an hour in each year.

Speeds have grown because of the smoother shapes used in construction and through the greater engine powers provided. Can speeds continue to rise indefinitely? We may have gone almost as far as we can in using ship-shaped forms, though we still know very little about the possibility of ensuring an increase in the extent of the laminar flow of the air over the surface of wings or body : if this could be done the resistance would drop considerably. So far as prospective increases in engine power are concerned, there is little publicly revealed in these days, but one hears of testing plants being adapted to deal with engines of no less than 3,000 h.p. apiece. But even with these increases a definite speed limit is being approached - not one imposed by the laws of any State but by the laws of Nature. As I pointed out two years ago in a presidential address to the Royal Aeronautical Society, there is good reason to believe that, although speeds of 500 m.p.h. may be attained, it is unlikely that $600 \mathrm{~m} . \mathrm{p} \mathrm{h}$. will be much if at all excecded, for the latter figure is some 80 per cent of the speed of sound, and when the latter is approached the drag rises to a level far ahead of any prospective engine improvements. Although nothing in the physiology of man forbids even higher specds, as witness the high orbital speed of the earth on which we all live with some measure of tempered comfort, there is soon imposed a physiological limit if high speed is combined with rapid manœuvre. If the latter is required, then the speed must be controlled to suit the conditions. Only the future can reveal how the balance between the two will be struck.

No simple summary can be given of what has been done as regards engine development, for, great as has been the change from the fifteen pounds per h.p. of the original Wright engine to the one pound, and less, of to-day, one remembers that in this one respect the engines of the last Schneider Trophy Race were as meritorious ; where the latter were much below modern standards was in their lack of reliability when working at this power ratio. To-day's engines run without attention for hundreds of hours, a very different matter from endurance for a short race.

Even if engines of 3,000 h.p. may be said to be in sight, they are still some way from achievement.
Progress depends not only on the skill of the engine designer and the metallurgist, but also on the ingenuity of the industrial chemist in producing his remarkable fuels-wonderful alike for their uniformity of quality and for their ability to resist detonation even when employed in engines of very high compression ratio.

Improvement in load-carrying capacity depends also on improvements in materials, though it is fair to designers to record the progress made in reducing the percentage which the structure forms of 'the total flying weight in modern aircraft. Nowadays as good a figure is shown for this in large flying-boats as in landplanes, a remarkable achievement. The flying-boat used to be thought of as slow and heavy, but to day it holds its own, in efficiency, whether aerodynamic, structural, or economic, with any other mode of flight.

The flying-boats of to-day represent a great technical advance in quality over their predecessors of ten, or even five, years ago, but they have not yet shown any marked advance in size. The fine fleet of Empire flying-boats is made up of 20-ton units; the new Short 'Golden Hind' class for the Atlantic weigh 33 tons apiece; the Boeing 'Yankee Clipper' has a total weight of nearly 40 tons; but the 'Dornier Dox' which long preceded them ran to 50 tons laden. On the other hand, there has been a great gain in speed and in carrying capacity. The Boeing boat, for example, is reported to carry $10,000 \mathrm{lb}$. of load over and above its 4,000 gallons of fuel : as this amount of fuel will waigh $30,000 \mathrm{Ib}$., this makes a total load of $40,000 \mathrm{lb}$., or almost exactly half of the total flying weight, the sam? as for the 'Golden Hind', and a truly remarkable percentage. The improved Empire flying-boats intended for the Atlantic crossing are planned to take-off at a flying. weight of about 20 tons and to take 3 tons of additional fuel after they are air borne, by supply from a flying tanker on Sir Alan Cobham's scheme. This will increase the load on the wings from $30 \mathrm{lb}$. to $35 \mathrm{lb}$. per square foot, and may be regarded as a first step towards what could be done with wings specially designed and stressed for high loading. The 'Golden Hind' class is designed for a range of 3,403 miles without refuelling, and this with full load. Its early programme may include a survey flight along the route to Latin America.

It is naturally impossible in the courss of this address to discuss all the many problems in the science of aeronautics which are being investigated at the present time. They are far too numerous and the time too short. But to som? of them I must refer. One of great importance and quite fascinating interest is the investigation of the change in the air flow over a wing surface from the laminar to the turbulent state. It is known that if 
the flow could be kept laminar, the drag would be vastly reduced, but it has yet to be discovered how to do this. A step in the right direction may lately have been made at the Langley Field Laboratories, for during Dr. Lewis's recent Wilbur Wright Lecture before the Royal Aeronautical Society mention was made of some wind tunnel tests in which a special form of aerofoil gave a drag co. efficient figure of only about one-third of that usual. Further particulars will be awaited with interest. Many laboratories and experimental stations are studying this same problem, and, as not infrequently happens in such cases, success, once met with, itself ereates a batch of new problems. For one thing it is clear that the presence of laminar flow can but be hindered by the use of the tractor type of airscrew now almost universal. It may be necessary to change to pusher designs, and as this will involve a marked rearward movement of the centre of gravity of the whole aircraft, all the stability factors will bo gravely affected, to say nothing of the many engine problems also raised.

Other special problems relate to the possibility of having wing areas adjustable in flight by telescopic or other means, to the study of the very considerable increase in the control forces required of the pilot in large machines of high speed capaeity, of the special problems raised by variable pitch airscrews, particularly in relation to the landing run, of the advantage at high air speeds of two-speed gear boxes, and of the special problems involved in pressure cabins.

The problem of the rotating wing is in a class by itself. Aircraft so fitted are quite unable to compete in speed with those with normal wings, but they easily beat the latter in take-off and landing. Many types are now in the field, the Cicrva, the Hafner, the Kay and the Focke, to mention no others. The scientific problems are largely solved, as are the great mass of the mechanical ones. What is required is such a degree of user as will call for this form of aircraft to be constructed in numbers. When that happens, rotary wing aircraft will benefit in their design by that skilled attention from the production engineer which alone seems able to produce results that really look right.

The growth in recent years of the interest taken by the public in aviation, over land and over sea, is most striking. Partly, of course, it is due to the increase in the Air Arm and all that is thereby implied. But there is also a very rapidly growing use being made of the abundant facilities for air travel offered by the civil air transport services. The United States is often thought to lead the world in this respect-as it certainly does in the use of the automobile-but I believe that in proportion to the size of the population, and that is the true criterion, the total mileage flown annually is larger in Australia than it is in any other single country in the world; and there is good reason to expect that that pre-eminence is likely to continue.

\section{THE Future YeARS}

Let us consider what lies ahead in the coming years in respect of speed, size and range. No doubt military craft will go as fast as they can. But since it seems that they cannot exceed 600 m.p.h. much if at all, there is little doubt that speeds between 500 and 600 m.p.h. will become usual. Not so, however, for the civil air services, where quiet, comfort and cost are all-important: here there is good economic reason for speeds to settle down in the 200-300 m.p.h. range. In both these classes we seem therefore to be approaching some degree of finality.

Altitude and range are alike in that so much depends on the discovery of new materials of construction and new ways of using them. Steady progress may be expected, though probably nothing sensational unless the use of reinforced plastics be so reckoned. For civil work the advantage of long-range flying depends on the ability to fly by night, and this is advancing rapidly. Radio services are improving and the vagaries of the ionosphere are becoming better understood. High altitude flying-whether in the stratosphere or just below it-requires the sealed cabin, and it will, I fancy, chiefly be sought by those whose first care is speed and whose lesser concern is cost.

When, however, we come to think of such other factors in the future of flying as the size of the craft, and the wing loading employed, we are concerned with quite other considerations. Size depends mainly on engine power, for there is a limit to the number of power units which can be conveniently looked after. Even if we have tractor and pusher airserews in tandem (and tractor screws may well become unpopular where the highest acrodynamic efficiency is sought), six such pairs may be the practicable limit. This would give us twelve engines, which, at 3,000 h.p. apiece, makes the total power 36,000 h.p. At $15 \mathrm{lb}$. carried per h.p. available, this would give a total flying weight of $540,000 \mathrm{lb}$. or some 250 tons. Such a craft would naturally be a large boat, taking two hundred passengers or more; and that is the largest flying craft that can be said to be now in sight, although I ought perhaps to mention that in a lecture to the students of the Royal Aeronautical Society, who alone perhaps might be expected to live to see it, Dr. Roxbee-Cox was bold 
enough to include an American forecast for a boat of 3,120 tons! But difficult as it may be to foretell accurately the future of the large flyingboat, there can be little doubt that we shall soon sce such craft in active compctition with their older rivals-which use the surface of the sea-for all rapid fassenger transport on the important Atlantic routes.

\section{The AIR ARM}

Among the world's many political preoccupations there is no more pressing or more intractable problem than that of curbing in some way the universal growth of armaments. It is true that, in so far as the product is entirely produced within the country of origin, the mere cost is of little moment. One makes armaments instead of making something else, and in the case of a people who loved above all having lots of lethal weapons, there would be nothing more to be said, though the taste might be thought odd!

It is not, however, solely a matter of finanee, since normal peoples would much prefer the energy directed to armament production to be given to articles of service in civil life such as houses, pictures, sailing-boats, holiday camps and the like ; and for the general body of such activity to be guided into channels which fit in with the quantity and quality of the labour available in the country. Morcover, just as a house containing a store of high explosives is not looked on as a happy abode, so there is always a fear that in highly armed international life a trigger in some remote spot may be pulled by accident, or by mischief, with irreparable harm to the whole world.

When some years ago an effort was made to come to an international understanding about air armaments, success was not attained. This was due, it is truc, in some measure to the existence of strong professional interests and to the relative lack of attention to the needs of the ordinary man, but it was partly due to the inherent difficulty in the then state of the art of distinguishing between military and civil types. Even suppose, it was asked, that one could abolish all military aircraft, how would one deal with the civil types which could ke so casily converted? In those days this was a germane question. But is it now? I think not, and for this reason.

The specds of military aircraft are now in excess of $400 \mathrm{~m}$.p.h. and will rise still higher. But civil aircraft rarely go faster than 250 m.p.h., and it is doubtful whether it is cconomically advantageous to have even so high a speed as that. This at once makes a great difference in the types. Again, the comfort and space needed for civil transport tends to produce a design of body which does not in the least resemble military requirements. In so far as the civil types in their really large sizes come more and more to take the flying-boat form, so are they the less like military types. Perhaps I should say here that I am leaving aside reconnaissance dutics and troop-carrying, and thinking mainly of the aggressive type, the bomber.

Hence I submit that, as I suggested in a recent address at Chatham House, the position has been reached when, so far as technical considerations are concerned, an agreed limitation could be set on military production without the effort being nullified by the existence of civil types to which no such limitations applied. It must be remembered, however, that when a political man talks about 'parity in the air', he may not really understand what he is saying. What he probably means is equality in offensive force, for mere parity in numbers might be got by the absurd equation of putting 100 bombers plus 1,900 interceptor fighters as equal to 1,900 bombers plus 100 interceptors, because both sides add up to 2,000 . It cannot worry any peace-loving country if one of its neighbours builds 1,000 or 10,000 interceptor fighters, any more than it would if that neighbour built immense numbers of anti-aircraft guns and searchlights. In fact, as a gain to the general strength of defence it would be rather comforting than otherwise.

In my view there will be no reason, once the international situation has cleared, why there should not be an agreed limitation in respect of numbers or tonnage of bombing aircraft-leaving the interceptor fighters entirely aside. It would be but cautious to agree on a limit to the speed of civil types, but as this would merely confirm what economic requirements would themselves suggest, it need be no hardship ; excessively high speeds for eivil types do not pay, are much more dangerous to passengers, are much more noisy to everyone, and need wasteful forms of air ports.

When this difficulty of our own age has been at last happily solved, we may be very content to leave our successors the even more threatening menace of dealing aright with the problem of atomic energy. This it is not necessary for me to describe. I will only say that, in a recent broadeast address, Prof. J. D. Cockeroft spoke of an atomic trigger action between the metal uranium and a single neutron which is reported to be capable of releasing a $100,000,000$ fold increase in energy! Perhaps there are immense practical difficulties in doing this on a large scale; I earnestly hope there are! For oursclves we may well consider that in our own day we are quite sufficiently occupied with the thoughtful handling of our own special prob. Icm, how rightly to guide the future of flying. 